\title{
Compensating the Multinationals: Chile and the United States Copper Companies
}

\section{Carlos Fortin}

In 1971 the government of Chile under President Salvador Allende nationalized the partly American-owned copper companies that made up the so-called Large Copper Mining sector (Gran Mineria del Cobre), namely those exploiting mines with a production capacity of at least 75,000 metric tons a year. ${ }^{1}$

The nationalization gave rise to a sharp conflict between Chile and the American companies which resulted in legal and commercial reprisals being undertaken by the companies both in the United States and in Western Europe, and was by all accounts an important factor in determining the policy of economic isolation of Allende pursued by the American government and by international organizations with strong American influence.

That conflict is now ended following the completion of compensation agreements between the American companies and the present Chilean military regime according to which the firms involved stand to receive far more than under the terms of the 1971 nationalization, the orders of magnitude being, in fact, comparable to those discussed with the companies ten years before. This article will attempt to describe and tentatively evaluate the agreements, placing them in the context of those previous instances in which issues regarding payment for nationalized property were raised between the Chilean government and the American companies, and suggesting factors that may account for the high repayment terms agreed upon.

\section{The Frei agreements: valuation and compensation}

The question of the compensation for the acquisition of American copper interests in Chile arose for the first time as a major political issue in connection with the partial nationalizations effected by the government of the Christian Democratic President, Eduardo Frei (1964-70).

1 The companies included were those operating the mines of Chuquicamata and Salvador, in which The Anacond Company was a 49 per cent shareholder; El 'Teniente, with 49 per cent equity belonging to Kennecott Copper Corporation; and Exotica, with a 75 per cant Anaconda interest poration; and Exotica, with a 75 per cant Anaconda interest. Also nationalized was the Andina company, in which Cerro
Corporation had a 70 per cent interest and which was contemplating expanding above the 75,000 metric tons mark within the next few years. Together the five mines accounted in 1970 for 78 per cent of the total copper production in Chile and for 59 per cent of the total value of Chilean exports.
In 1967 the Chilean government purchased 51 per cent of Kennecott's interest in the Teniente company, as part of a global agreement that included a significant tax reduction for the new joint venture and an expansion programme costing approximately $\$ 230$ million. The price offered for the 51 per cent equity was $\$ 80$ million, which was $\$ 13$ million more than the total book value of Teniente. Kennecott had argued that the book value under-estimated the real worth of the fixed assets of the company, and requested an outside appraisal to determine their current value. The Chilean government agreed and an appraisal carried out by a US firm produced a figure of over $\$ 244$ million, raising the total book value to $\$ 286$ million. As it was politically difficult for the government to pay more than $\$ 100$ million, further $\operatorname{tax}$ concessions were offered to persuade Kennecott to accept that only $\$ 160$ million be entered as capital, the rest being imputed as reserves. $^{2}$

The sum of $\$ 80$ million was paid by Chile in cash between 1967 and 1970. However, an additional agreement established that Kennecott would lend back to the new joint venture the instalments paid by the Chilean government, plus interest, to contribute to the expansion plan. This loan amounted to $\$ 92$ million and was repayable over a period of 15 years starting in 1971 with an annual interest of $5 \frac{3}{4}$ per cent per year. As far as Kennecott was concerned, this was in fact the payment for the 51 per cent interest acquired by Chile; Chile, however, had had effectively to transfer that amount from its own resources to the new company in the preceding four years. Other features of the agreement included a reduction in Kennecott's tax burden as minority shareholder from over 80 per cent to 44 per cent of gross profits, a level that was furthermore guaranteed by the government for a period of 20 years. Additional contracts gave Kennecott the

2 This valuation has been the subject of considerable controversy. The point has been made that if the book value was less than the real worth of the assets, this could only be due to accelerated depreciation or to imputing to operational costs expenditures that were really of a capital nature. In both cases there is avoidance of taxes by means of artificially inflating costs. In the first case taxes are postponed, and hence the procedure amounts to an interest-free loan of the government to the company; in the second case capitalization taxes are avoided altozether. See $\mathbf{K}$. Griffin, Underdevelopment in Spanish America, George Allen and Unwin, London), 1969, p. 154. E. Novoa. La batalla por el cobre (Editorial Quimantu, Santiago), 1972, provides a general description and critique of the Frei agreements. 
management of the mine and control over the sales of copper and the purchase of inputs for periods of between 10 and 20 years.

Taken as a whole, the terms of the agreement with Kennecott offered quite generous compensation for the transfer of ownership of 51 per cent of its interest in Chilean copper. In the end Kennecolt had written off its books assets for $\$ 34$ million (51 per cent of the 1966 book value) but had added a credit for $\$ 80$ million and retained a 49 per cent interest in a company which was now worth $\$ 286$ million. At the same time it had secured for its Chilean subsidiary a twenty year tax regime that cut its tax liabilities in half, and had retained control over the operation of the company for a similar period.

The reason for this generosity on the Chilean side is probably two-fold: on the one hand, the Frei government badly needed to be able to show a concrete result of its much emphasized copper policy, particularly in the face of hostility both from the parties of the left, that were pressing for complete nationalization, and from right-wing sectors, that were strongly against Frei's other main policy, the agrarian reform programme; on the other hand, the world copper price level and its future prospects appeared good. In fact, the actual level of prices far exceeded the expectations of the government negotiators, and as a result Kennecott enjoved extraordinarily high profits in 1967-69. The same was the case with Anaconda, which in 1967 had refused to accept joint ownership with Chile and had offered instead, in exchange for tax reductions, an investment programme of about $\$ 126$ million to be financed from its own resources. ${ }^{3}$

It was precisely the political furore prompted by the windfall profits of the companies that forced the government in 1969 to introduce changes in the companies' regime. This time it was. agreed that Anaconda would sell to Chile 100 per cent of its interest in Chuquicamata and Salvador. This would be done in two stages. In the first, following the Kennecott model, joint ventures were constituted and Chile bought 51 per cent of the shares. The price paid was based on the book value of Anaconda's subsidiaries at the end of 1969. Promissory notes were issued by Chile in

3 The last element of the 1967 agreements was the establishment of a joint venture with Cerro Corporation for the exploitation of the Rio Blanco mine. The new company called Compañía Minera Andina was 70 por cent owned by Cerro (30 per cent by the Chilean State) and an initiai investment of $\$ 89$ million was agreed, to be financed with external credits. the amount of about $\$ 175$ million corresponding to 24 six-monthly instalments beginning June 1970 with an annual interest of six per cent. Anaconda retained the management of the new companies and the sales of copper and procuring of inputs for a period of eight years, and was to be paid for these services a fee of one per cent of the total value of sales per year.

As for the remaining 49 per cent of the shares, Chile undertook to purchase them by 1982 , at a price based on the annual average profit of Anaconda as minority shareholder from January 1970 to the time of the purchase, multiplied by a factor of eight. ${ }^{4}$ It was also agreed that a preferential dividend be established in favour of Chile on the profits of the joint ventures whenever the price of copper rose above 40 US cents per pound. This agreement was conditional upon Kennecott accepting a similar arrangement, which it eventually did.

In some respects the agreement with Anaconda in 1969 was more favourable to Chile than the agreement with Kennecott in 1967, and no doubt this is at least partially due to a political climate generally hostile to the companies mentioned above. Thus book value was used to determine the price of the 51 per cent; the preferential dividend in favour of Chile was established from the outset; and no down payment was contemplated. In other respects, the two were quite similar: again control over management, sales and purchases remained in the hands of the American company. In fact, here Anaconda fared better than Kennecott, as it was to be paid a handsome fee for the services.

In one main respect, the Anaconda agreement was more favourable to the company than the Kennecott one, particularly considering Anaconda's corporate policy of rejecting partial divestiture as a more or less permanent solution, and that is in the price to be paid for the 49 per cent of the equity. Even though Anaconda did not challenge book value as a true reflection of the worth of the assets, the system agreed upon could have easily yielded figures more than twice as high as book value, depending on the price of copper and the time of the purchase.

\section{The 1971 nationalization: compensation and excess profits}

Salvador Allende took office on 4 November, 1970; the bill proposing the nationalization of the

\footnotetext{
4 If the purchase were to be made in 1974; beginning 1974, the factor would decrease by 0.5 yearly until 1977 and remain constant thereafter.
} 
copper companies, in the form of an amendment to the Chilean constitution, was submitted to Congress on 21 December that year. After seven months of debate, the nationalization bill was passed unanimously by Congress, including members of all Chilean political parties. It nationalized the companies of Gran Mineria and Andina as whole legal and economic entities, that is, including both assets and liabilities, and provided that they had a right to compensation at book value as of 31 December, 1970, less:

(a) any revaluations done by the companies after 31 December, 1964. This applies specifically to the Teniente revaluation of 1967 ;

(b) the value of rights to mining deposits that may appear in the books of the companies, since according to Chilean law mining deposits are the property of the State; and

(c) the value of assets that the State receives in defective operational condition or without service rights, repairs and spare parts.

In addition, the amendment also established that the President of Chile could order a deduction of all or part of the excess profits received by the companies since 1955 (i.e. the year in which the American subsidiaries were compelled by law to keep accounts in Chile). A judicial procedure was established to determine the final amount of compensation, and the President was empowered to decide on the form, period and interest of payment of the compensation, which should be in cash within 30 years and with an interest of no less than three per cent per annum. The compensation thus arrived at superseded any previous agreements for the purchase of shares.

In order to establish the criteria for normal profitability, a number of studies were carried out by Chilean technical agencies, the basic one being the comparison between the profitability of the American companies in their world operation and in their Chilean operation as a percentage of the respective book values. The summary results are as follows:

table 1

Anaconda and Kennecott: annual average profits as percentage of book value, $1955-70$

\begin{tabular}{lcccc} 
& & \multicolumn{3}{c}{ world excl. } \\
Anaconda & $\ldots \ldots$ & 7.2 & 3.5 & $20.2^{*}$ \\
Kennecott & $\ldots \ldots$ & 11.6 & 10.0 & 34.8
\end{tabular}

* Chuquicamata

Source: P. Nudelman. La compensación a las compañias del cobre nacionalizadas por el Gobierno de Chile Santiago, mimeograph, 1973.
The President finally decided to consider as normal a profit of 12 per cent on book value and ordered a deduction of all profits exceeding that percentage.

The final calculations of compensation done by the Comptroller General of Chile are as follows:

table 2

Chile, 1971: calculation of compensation to the nationalized copper companies

(\$ million)

\begin{tabular}{lrcrrrr} 
& \multicolumn{7}{c}{ Chuqui- Salva- Exo- Ten- } \\
& camata & \multicolumn{2}{c}{ dor } & tioa iente & Andina \\
book value & 242 & 68 & 15 & 319 & 20 \\
$\begin{array}{l}\text { deductions for: } \\
\text { mining rights }\end{array}$ & & & & & \\
$\begin{array}{l}\text { and defective } \\
\text { assets }\end{array}$ & -18 & -6 & -5 & -21 & -2 \\
revaluation & 0 & 0 & 0 & -198 & 0 \\
$\begin{array}{l}\text { compensation } \\
\text { deduction for }\end{array}$ & 224 & 62 & 10 & 100 & 18 \\
excess profits & -300 & -64 & 0 & -410 & 0
\end{tabular}

Source: Comptroller General's Resolution on Compensation, 11 October 1972. Figures have been rounded to the nearest million dollars.

As suggested before, the decision on excess profits precipitated a conflict with the American companies. Chile did not honour the promissory notes held by Anaconda for the 51 per cent equity that fell due on 31 December 1971. In February 1972 Anaconda obtained in New York an order of attachment of goods, assets and bank accounts belonging to the Copper Corporation of Chile and the Chilean Development Corporation, to cover the value of the notes. Attempts by Chile to have the attachment vacated were unsuccessful and as a result Chile started experiencing difficulties in procuring spare parts for the mines, as 95 per cent of the imported inputs were of American origin and many could not be obtained elsewhere. It would also appear that Anaconda exercised influence on the main suppliers of the Chilean mines to induce them to stop selling to Chile, or to harden their commercial terms.

Kennecott, for its part, first tried to obtain a judicial review in Chile of the excess profits decision. When this failed in September 1972, the company launched a legal offensive in Europe, which was initially successful in attaching Teniente copper or the proceeds of its sale in France, Holland and Germany. Although by early 1973 all attachments had been vacated, the ordinary proceedings to determine the ownership of the copper continued through that year, and 
similar proceedings were instituted in Italy and Sweden. Kennecott also put pressure on European firms to get them to stop buying Teniente copper.

The basic legal argument of Anaconda and Kennecott was that the nationalization was null and void according to international law and the legal system of the European countries involved because it was not followed by compensation. In fact some compensation was being paid. Kennecott continued to receive payment from Chile for the $\$ 92$ million loan, which, as suggested, was really the payment for the 51 per cent purchased by Frei. This sum was about $\$ 8$ million less than the total book value of Teniente in 1971 excluding the revaluation. Anaconda had not been so fortunate, having received about $\$ 36$ million corresponding to the first three instalments for the 51 per cent of Chuquicamata and Salvador plus interest. In both cases the fact that Chile accepted responsibility for the outstanding debt of the nationalized companies meant that there was indirect compensation for the amount of the debt. In the case of Teniente, the liabilities as of December 1971 amounted to about 75 per cent of the gross value of assets excluding the revaluation, and about 45 per cent of that value including the revaluation. In the case of Chuquicamata and Salvador the corresponding figure is about 43 per cent. Compensation was also to be paid to Anaconda for Exotica, and to Cerro for Andina at levels very close to their book value, since those companies only started operation in 1970 and therefore there were no excess profits to be deducted. (See table 2)

This preceding argument was, of course, unacceptable to the companies. Kennecott stated that a satisfactory settlement would at a minimum entail payment of the revalued book value of the 49 per cent, i.e. about $\$ 176$ million Anaconda on the one side started the legal fight for payment of the outstanding promissory notes for the 51 per cent purchase-amounting in all to $\$ 153$ million -and on the other took a write-off for tax purposes in the US for $\$ 303$ million plus a claim for $\$ 159$ million against the Overseas Private Investment Corporation (OPIC), a US federal agency that insures American investment against political risk in underdeveloped countries. The total of its clatimed losses was $\$ 474$ million including $\$ 12$ million corresponding to Exotica which were later paid by OPIC. ${ }^{5}$

5 For Kennecott, see Kennecott Copper Corporation Expropriation of E1 Teniente, New York, 1971; for Anaconda, The Wall Street Journal, 25 July 1974.
The one American company with which there was no open conflict following nationalization was Cerro, whose subsidiary Andina was awarded a compensation of $\$ 19$ million, of which Cerro was entitled to slightly over $\$ 13$ million. The Allende government announced it was prepared to pay this amount in 29 six-monthly instalments beginning 31 December 1973, with a net interest of seven per cent. This settlement was termed 'reasonable' by the company which further announced its intention to continue working with the Chilean government in the operation and development of the Rio Blanco mine. In addition, Chile recognized a debt to Cerro for an $\$ 18$ million loan to Andina and offered to pay in the same terms as the compensation.

The conflict with the companies became a major element in the international position of the Allende government. Even though the legal offensive of the companies had limited success in disrupting the operation of the mines or the sales of Chilean copper on the world market, the compensation issue was an important factor in determining the interruption of grants and credits to Chile from the American government, and in particular the Export-Import Bank, that provided financing and guarantees for the bulk of Chilean imports from the United States. ${ }^{6}$ American pressure was also a main factor in stopping the flow of credits from the Inter-American Development Bank, that lent Allende a total of $\$ 11.6$ million in three years while the yearly average of loans in 1965-69 had been $\$ 40$ million; and from the World Bank, which did not extend any credit to the Allende government. ${ }^{7}$ The American government further refused to renegotiate the Chilean debt. The effect of this blockade of credits was to add considerably to the foreign exchange difficulties that Allende had to face, particularly in 1972 and early 1973 when low copper prices and an increase in the import of agricultural products combined to put enormous pressure on the country's balance of payments.

\footnotetext{
6 Following the recent revelations about CIA interference in Chilean politics with the purpose of 'destabilizing' the Allende government, there have been unchallenged reports in the US press to the effect that the American government exercised systematic pressure on private banks to stop credit to Chile. In fact, the short-term lines of credit to Chile of the American private banking system decreased from about $\$ 220$ million in 1970 to about $\$ 30$ million in 1971. The timing of these moves by the American government would suggest, however, that they were only partially caused by the copper issue, and that there was a more general rejection of the Allende government, which not even a settlement with the companies would have removed. See The New York Times, 15 September 1974.

7 J. Collins, "Tightening the Financial Knot", IDOC, no. 58, December 1973, pp. 70-74; P. Sigmund," "The 'Invisible Blockade' and the Overthow of Allende", Foreign Affairs, vol. 52 no. 2 , January 1974 , pp. $322-340$, accepts the point with respect to IDB while arguing generaily that there was no 'invisible blockade'.
} 
In view of this situation, the Allende government requested from the American government the application of the Treaty for the Peaceful Settlement of Disputes signed by the two countries in 1914 and the suspension of the economic sanctions, while the Investigating Commission called for by the Treaty issued a report. The United States government refused on the grounds that the Investigating Commission's report was not binding but only a recommendation, and pressed for a concrete settlement of the compensation question on bases different from those of the Chilean constitutional amendment that nationalized copper. A major concern of the American side in this connection was the need to remove the precedent of the retroactive deduction of excess profits, lest American interests all over the world could be endangered. This was not acceptable to Chile and so the impasse continued until the military coup that deposed the Allende government in September 1973.

The military regime and the American companies Shortly after the coup the new military rulers of Chile announced their intention to settle the compensation issue with the American companies. This was, of course, far from surprising considering that the economic policies of the new regime call for a substantial influx of direct foreign investment. Negotiations were started at the end of 1973 and by October 1974 agreement had been reached with respect to all operations except Exotica, and all legal actions of the companies had been discontinued.

The agreement with Cerro was signed in March $1974 .{ }^{8}$ The total amount to be paid is $\$ 41.8$ million, including the $\$ 13.2$ million that the Allende government was prepared to pay for compensation, the $\$ 18$ million loan also recognized by Allende and a sum of $\$ 10.6$ million for what the published reports term 'unspecified commitments'. Payment is to be made with $\$ 3.2$ million in cash and a 17-year note bearing interest of 9.2 per cent net a year. The compensation offered is, then, $\$ 10$ million more than what the Allende government would have paid; the time period is two years longer but the interest is considerably higher. Furthermore, the agreement includes the possibility of much faster repayment through the sale to Cerro of concentrates and slags from the Rio Blanco mine whose proceeds would amortize the debt. Although Rio Blanco's production of about 55,000 tons of concentrates a year is mostly tied up in long-term contracts,

8 Latin America Economic Report, London, 12 April 1974, p. 59 . there still remains a sufficiently large uncommitted tonnage to make it possible to effect repayment in a period of considerably less than 17 years. Lastly, in December the Chilean Copper Corporation announced that it had appointed Cerro as the sole agent for the sale of Chilean copper in the US and Canada, a development that in all likelihood is not unconnected with the compensation agreement, as an agency contract of this kind has a definite value for the American company.

The second agreement was with Anaconda, with which a Settlement Contract was signed in July 1974. Although the complete text has not been made public, the Decree-Law approving the Contract and the public announcement by the Minister of Mines of the Chilean junta ${ }^{9}$ disclosed the following features:

(i) the basis for compensation is the book value of the companies as of 31 December 1970, less certain unspecified deductions. It seems clear that there were no deductions for excess profits.

(ii) Chile will pay for the remainder of the 51 per cent purchased in 1969 the sum of $\$ 194$ million of which $\$ 6$ million will be paid in cash and the rest by means of 19 equal promissory notes due every six-months starting 1 February 1975 with a net interest of six per cent per annum.

(iii) Anaconda is to receive a cash payment of $\$ 44.4$ million and $\$ 15$ million respectively for the 49 per cent of the shares of Chuquicamata and Salvador. The Chilean announcement states that this figure takes into account the time elapsed between 31 December 1970 and 30 June 1974, and that deduction has been made of taxes owed by the Anaconda subsidiaries in the amount of $\$ 34.7$ million.

The amount granted to Anaconda, then, is composed of the $\$ 253.4$ million of the settlement, plus $\$ 21.8$ million paid on the 51 per cent of the shares in $1970 / 71,10$ plus $\$ 34.7$ million of taxes that were offset against the compensation figure, for a total of $\$ 310$ million. This is $\$ 24$ million more than the Comptroller General's assessment of the book value of the two companies in December 1970 without any deduction for excess profits. The $\$ 24$ million figure is approximately equal to the interest on the amount outstanding of the 51 per cent for the period June 1971-June 1974. The Chilean announcement maintains that the agree-

9 El Mercurio, Santiago, 25 July 1974.

10 Including interest, the actual amount paid was $\$ 36$ million. 
ment is advantageous for Chile since Anaconda was in addition entitled to damages of about $\$ 24.5$ million for the non-payment of the promissory notes due between December 1971 and June 1974. This estimate, however, seems to calculate damages at the rather extraordinary rate of 12 per cent compound interest every six months, i.e. four times the original rate of interest on the debt. Furthermore, it could be argued that the cash payment-which is really composed of the $\$ 65$ million plus the setoff for $\$ 34.7$ million-can be considered to be a higher present value than the same amount spread over ten years at six per cent per annum. The discount rate for Anaconda is probably quite high, due to the abnormal political situation in Chile and the fact that the immediate reaction of the Chilean opposition in exile was to state that the agreements violated the Constitution and were not to be recognized by any government that would succeed the military. All in all, the agreement seems to compensate fully the American company for the nationalized assets, even though it falls short of the figure announced by Anaconda in 1972 as the value of write-off and insurance claims. Anaconda has announced that it will continue its legal action to obtain payment from OPIC, but in the event it is successful it will pay a percentage of the $\$ 253$ million to the agency. 11

Finally, the agreement with Kennecott was signed in October 1974. According to the announcement by the Chilean Minister of Mines, ${ }^{12}$ Kennecott is awarded a compensation equal to 49 per cent of the book value of Teniente in December 1970, less unspecified deductions that include $\$ 19.6$ million for outstanding taxation. The net compensation is then put at $\$ 44.8$ million to which is added a sum of $\$ 9.1$ million corresponding to six per cent interest per year for the period January 1971-September 1974. Lastly, a sum of $\$ 14$ million is awarded corresponding to dividends and interests thereon for the 49 per cent equity up to 31 December 1970 , of which $\$ 6.5$ million are paid in cash. The remainder, as well as the main sum, is paid in 19 six-monthly instalments starting 25 April 1975 with an annual net interest of six per cent.

In all, Kennecott is awarded $\$ 68$ million plus $\$ 19.6$ million of tax setoff. Added to the $\$ 80$ million of the 51 per cent equity this amounts to about $\$ 70$ million more than the unrevalued book value in 1970 less defective assets according to

11 "News from Anaconda", 24 July 1974.

12 E1 Mercurio, 25 October 1974. Partial English translation in Metal Bulletin, no. 5936, 29 October 1974, p. 20. the Comptroller General's estimate. The sum is, however, $\$ 130$ million less than the revalued book value as of December 1970 minus defective assets. Again, the deduction for excess profits called for by the constitution is eliminated.

Kennecott, then, seems to have agreed to a compensation for the 49 per cent equity that is about one-half of its stated claim of $\$ 176$ million, although it is close to twice what it would have received according to the 1971 nationalization bill even in the absence of deduction for excess profits. In effect, it has dropped its claim to the revalued book value as the fair assessment of the worth of the assets.

That this was probably not an easy step is no doubt shown by the fact that the Kennecott agreement took a full three months more to achieve than the Anaconda settlement. One can only speculate as to the reasons for their eventual willingness and one that immediately springs to mind is the possibility of US government pressure. The American government's eagerness to help the Chilean junta was apparent at an early stage. In the two months following the coup, direct bilateral assistance was given in the form of commodity credit loans for $\$ 52$ million. Eximbank reopened its credit and guarantee programme for Chile and the Inter-American Development Bank, clearly reflecting a change in the American position, had granted credits for \$201 million as of April 1974. For fiscal year 1975, the US government proposed to Congress about $\$ 85$ million of aid to Chile, including \$25 million in AID development loans -interrupted since 1967 -about $\$ 1$ million in grant assistance (compared with $\$ 330,000$ in 1973), $\$ 37$ million in 'food for peace' grants and loans-as against $\$ 2.5$ million in 1973 -and some $\$ 21.5$ million in militiary aid, about twice as much as in 1973.13 Furthermore, the Chilean military were quick to do away with what was the most politically dangerous element in the Allende nationalization, namely the deduction for excess profits. This in itself probably made the possibility of an early settlement with the companies a desirable objective in the view of the American government.

Despite the reduction in Kennecott's original claim, the settlements represent a quite onerous

13 The AID proposal to Congress is justified as follows: "Given the willingness of Chilean authorities to co-operate in the resolution of outstanding bilateral problems of debt and compensation, the efforts underway to regularize Chile's international financial obligations, and the serious Chilean stabilization effort, reactivation of the AID loan programme is proposed for F"Y 1975". Quoted in Inter-American Economic Affairs, vol. 28 no. 1, Summer 1974, p. 89. 
burden on the Chilean balance of payments. For 1974 total payments amount to $\$ 74.7$ million plus about $\$ 11$ million of the Kennecott debt of $\$ 92$ million.

In 1975 , payments of principal and interest to Anaconda will total about $\$ 30$ million 14 ; the corresponding figure for Kennecott will be about $\$ 10$ million ${ }^{15}$; and for Cerro, assuming no acceleration of the repayment, it will add to little less than $\$ 6$ million $^{16}$. If one allows for some payment for Exotica, about which no agreement has yet been announced, but which is a much less conflictive issue, the annual payments beginning in 1975 may amount to over $\$ 55$ million.

The decision to assume this heavy financial obligation was probably eased for the Chilean military by the fact that the sum of the direct US government aid given to them after September 1973 plus the proposed amount of aid for fiscal year 1975 is approximately equal to the payments to the companies for 1974-75; another factor was probably the record levels reached by copper prices in early 1974 and the general expectation that they would stay at comparatively high levels for the remainder of 1974 and 1975. As it happened, however, the recession in the Western economies caused a considerable drop in the level of prices in the second half of 1974: the average for July-December was $£ 660$ per ton as compared to $£ 1,100$ per ton in January-June. Despite the attempt by producers belonging to the Intergovernmental Council of Copper Exporting Countries (Chile, Peru, Zaire and Zambia) to raise the price by cutting down sales by 10 per cent, all indications seem now to be that the price in 1975 will not greatly exceed the levels of late 1974. On the other hand, the US government has had serious difficulties in getting Congressional approval for the proposed aid to the military junta, due to the concern about violation of human rights in Chile. In December 1974 a Senate-House Conference voted to suspend all military aid to the Chilean dictatorship, and it seemed very likely that the decision would be confirmed when it reached the floor of both Houses.

The cost of the compensation agreements, therefore, may well end up more burdensome to the

\footnotetext{
14 Two promissory notes for $\$ 9.9$ million each plus interest for $\$ 5.6$ million and $\$ 5.4$ million.

15 Two promissory notes for $\$ 3.2$ million each plus interests for $\$ 1.8$ million and $\$ 1.75$ million. One should, again, add the $\$ 10$ million of the old debt.

16 One payment on the principal for $\$ 2.3$ million plus $\$ 3.5$ million interest.
}

Chilean military regime than they first anticipated. But then that seems to be the price they are prepared to pay to placate the American multinationals and, they hope, reopen the flow. of direct foreign investment to the country.

\section{POSTSCRIPT}

On 5 December 1974 the Chilean junta and the Overseas Private Investment Corporation of the United States agreed on the compensation to be paid for the nationalization of the Exotica mine. It amounts to $\$ 12$ million payable over a period of five years with a net interest of 6 per cent per year. This completed the settlement of all outstanding claims deriving from the nationalization. of Gran Mineria.

According to a report in the Financial Times of 6 March 1975 the junta has further announced that it will allow international mining corporations to wholly own new copper mines producing 100,000 tons or more a year. This reverses a policy announced in 1974 according to which the Chilean State would maintain at least a 51 per cent interest in new mines of this size to be developed by foreign investors. 